Open Access

\title{
Bridal photos and diamond rings: the inequality of romantic consumption in China
}

Wanning Sune

\author{
Correspondence: \\ wanning.sun@uts.edu.au \\ University of Technology Sydney, \\ Broadway, NSW, Australia
}

\begin{abstract}
Although sociological insights into the relationship between consumption and class are mostly borne out by current research in the Chinese context, it is important to consider the implications of applying such an analytic framework - which arose within American and European social contexts-to contemporary China. This paper examines the relationship between consumption and class relations. Drawing on ethnographic research and interviews with young urban professionals in Beijing and Nanjing and young rural migrants in Shenzhen, it asks how individuals from these two socioeconomic cohorts participate in the ritual of romantic consumption. In particular, the paper asks how individuals from these groups think about and rationalise their decisions surrounding two wedding-related consumer items: bridal photography and diamond engagement rings. The discussion reveals some distinct features in class formation in contemporary China, where class structures are fluid, unstable and still in the process of being defined.
\end{abstract}

Keywords: Inequality, Class, Consumption, Romantic consumption, Democratisation of luxury goods

The relationship between class and consumption has long been well established. Sociologists consider consumption to be a key class marker and believe that class positions are negotiated through consumption in complex and often paradoxical ways. While Marx defines class in terms of one's position in relation to the means of production, Weber, on the other hand, considers consumption to be a key indicator of status group. To Weber, status is determined by the power that comes from the 'social honour or prestige' distributed within the status order (Weber 1922: 926-927). What confers such honour and prestige is, according to Bourdieu (1984), cultural capital. To Bourdieu, consumption is bound up with taste, which manifests as one's familiarity with legitimate culture. In sociological literature, consumption has long been viewed as a 'social, cultural and economic process of choosing goods', and as such, it constitutes an 'institutional field' which bridges economic and cultural institutions, large-scale social change and the formation of selfidentity (Zukin and Maquire 2004: 173). Since individuals engage in the process of consumption as a project of expressing and forming identity, the role of consumption in constructing and shaping social identities is crucial.

Chinese scholars who are concerned with change in social structures in contemporary China use a number of labels and terms, ranging from 阶级(class), 阶层 (stratum)

(c) The Author(s). 2017 Open Access This article is distributed under the terms of the Creative Commons Attribution 4.0 International License (http://creativecommons.org/licenses/by/4.0/), which permits unrestricted use, distribution, and reproduction in any medium, provided you give appropriate credit to the original author(s) and the source, provide a link to the Creative Commons license, and indicate if changes were made. 
and 群体 (social group). Reviewing this body of Chinese-language literature, Guo observes that in contemporary China, 'class' is considered as a historical revolutionary instrument, whereas stratum is widely adopted as a more appropriate sociological concept to describe and analyse actual social structures. The shift of analytical focus from production to consumption-motivated by a belief that the impact of consumption is a 'far-reaching variable' on China's social relations-is believed to be an effective means to this end of sidestepping class relations (Tomba 2014: 97).

Despite the absence of class analysis, the emergence of the middle class is widely believed to be conducive to social harmony, stability and its political legitimacy (Chen and Goodman 2013). And since consumption, alongside income, occupation and education, is a key index of middle-class membership, it is not surprising that popular media and cultural representations of the middle class are mostly associated with their consumption and lifestyles (Guo 2008; Rocco 2017).

Since the early 1980 s, economic reforms have transformed China from a society consisting mainly of only two proletariat classes-workers and peasants-to a society whose class structures and relations have become increasingly complex and unstable. As China's social stratification deepens, new class identities are emerging, and class structures and class relations are being redefined (Li 2013). Consumption has also presented itself as key prism through which changing social structures in China in the reform era are understood. Real estate markets, for instance, provides a means of 'spatializing class' in urban China (L. Zhang 2010). Similarly, retail sector affords shoppers and sales people occasions to engage in strategies of class distinction (Hanser 2008). Class inequality can be experienced as embodied 'interactive labour practices' in the service and hospitality sector, whereby the bodies of workers function as 'signs, codes and messages' of class difference (Otis 2012: 9). Class relations are equally embodied in the interactions between 'intimate strangers'-employers versus domestic servants at home (Sun 2009) and patrons versus sex workers in the brothels.

The analysis of the relationship between class and consumption is particularly important in times of radical social restructuring. This is because consumption affords a key site in which class-related aspirations, anxieties and fears are simultaneously articulated and addressed. Invoking C. Wright Mills' figure of the 'new middle class', Rocco points to the instability of middle-class membership in contemporary China. The new middle class is in constant fear of losing everything. They live in an unstable world, and they are never sure where they are on the social ladder. They imitate the bourgeosie's lifestyle and they strive to avoid falling into the category of "workers"' (Rocco 2017: 206). For this reason, to investigate class and consumption in any given social context, we need to ask how individuals interpret consumer items and activities, and how their interpretations are imbued with class-related anxieties and aspirations. For instance, research suggests that some romantic and wedding-related consumption activities are shaped by the desire of people to emulate the practices of the social class immediately above their own, thereby vividly embodying what Veblen (2006) [1899] calls 'competitive consumption'. Romantic and wedding-related activities involve the consumption of what Hirsch (1976) calls 'positional goods'-defined as goods that derive their economic value from their scarcity. Consumption of positional goods allows those who can afford scarce commodities, such as pristine beaches and other luxury leisure goods, to enjoy prestige and superior status. At the same time, however, 
consumption can also be a levelling as well as a strengthening force in the social structure, since the 'democratisation of luxury goods' gives lower class consumers the feeling of moving up, while the appropriation and legitimation of 'lower class cultural practices' by the middle classes sometimes result in a merging of the cultural practices of different classes (Illouz 1997).

Ethnography of China's under-classes (e.g. Pun 2005; Yan 2008), while mostly focusing on their labour and production activities, nevertheless also uncovers the aspirational nature of consumption of rural migrants. However, with rare exceptions (e.g. Hanser 2010), few studies systematically attempt to compare the consumption practices of different socioeconomic groups. As a result of these gaps, we are unclear about how inequality shapes the formation of class identity through consumption. Equally problematic is a tendency in existing research to focus on the consumption of material goods and services, thereby overlooking the question of how inequality affects the distribution and consumption of symbolic goods such as respectability, status recognition, and achievement of upward social mobility. And still less do we know if and how these two dimensions-the material and the symbolic-are connected.

The juxtaposition of two social groups-rural migrant workers and young, educated professional classes-allows us to demonstrate how consumers in different classes in China engage in the competitive consumption of positional goods. Described in official language as members of the 'disadvantaged communities', China's rural migrant workers, an extremely diverse cohort in terms of place of origin, types of labour, generational difference and migration history, embody China's most intractable problem of inequality (Selden et al. 2013). The experiences of individuals also vary depending on the specificities of the local politics, economic policies and administrative regulations of the city in which they live. ${ }^{1}$ A Chinese Census published in 2016 reveals that the number of internal migrants has now reached 278 million (National Bureau of Statistics 2016). The majority of these internal migrants have rural hukou-a household registration system that favours urban over rural residents (Chan and Buckingham 2008). This means that even though they now live and work in the city, they have no access to a range of entitlements-housing, health care, education and employment-that urban residents take for granted. Due to their ambiguous status-urban labourers with rural $h u k o u$ - and precarious labour conditions, their social status is inferior to that of what are usually referred to as 'blue collar workers'-members of the urban 'working class'.

Among the rural migrant community, the number of second-generation rural migrant workers in China between 21 and 30 years of age is now estimated to be around $29.2 \%$ of the entire population, making them the largest age cohort. This means that if we add another $3.7 \%$ in the 16-20 age group (National Bureau of Statistics 2016), $32.9 \%$ of rural migrants are under the age of 30 . A 2009 survey suggests that $80 \%$ of the second-generation migrant labour force-mostly born in the 1980s and 1990s-is now single (All China Workers' Union 2010). Most of these workers are the offspring of first-generation migrants, and many of them were born or brought up in the city. They have little knowledge of or interest in farming, nor do they want to go back to their villages. At the same time, their prospects of settling in the city and enjoying similar entitlements to those of urban residents are hardly better than those of their parents. Ownership of a flat/house and a car-things that urban middle-class residents take for granted-is a pipe dream for most of them, and most migrant workers, 
especially men-are also daunted by the cost of getting married. Young rural migrants tend to work long hours and receive low wages, both of which pose significant barriers to their participation in leisure and consumption-related activities.

In comparison, young, university-educated professionals in their 20s and 30s enjoy more security, since they have the precious urban residency status that is denied to rural migrants. They are usually described in the popular media as the 'young white collar' (xiao bai ling小白领) class. Making every effort to get ahead professionally in the competitive job market, individuals in this cohort work hard to pay off mortgage$\mathrm{s}-$ although, with the help of their parents, some already own their home. 'Young white collars' are therefore faring much better than individuals of the 'ant tribe' (蚁族), who, despite having a university education and a white collar job, cannot afford to buy or rent a decent place of their own and have to make do with sub-standard shared rental accommodation (Saunders 2015). Yet, in comparison with 'gold collars' (金领)-those in their 40s and 50s who occupy managerial positions in the transnational corporate sector-the young white collars face more pressure and less security. Those still paying off their apartment often lament the high cost of living in the big city and dread the extra financial burden associated with bringing up a child 1 day in the future. Nevertheless, individuals from this group aim to strike a balance between work and leisure, and increasingly, they reward themselves with high-end consumer items such as overseas tourism and luxury goods, especially before the arrival of any children.

How do individuals from two different social cohorts in contemporary China think about and rationalise their myriad consumption-related decisions-what to purchase, how much money to spend and for what purposes? In what ways do these 'consuming subjects' (Zukin and Maguire 2004) simultaneously articulate and address their classbased aspirations and anxieties through their consumption choices? And how do answers to these questions in turn tell us about class formation in the contemporary Chinese context, where new class identities are emerging, and where class structures and class relations are still in the process of being redefined? This paper aims to pursue these questions.

\section{Social inequality and the democratisation of luxury goods}

Given the age span which captures these two socioeconomic cohorts, it is understandable that romantic and wedding-related activities present themselves as an effective prism to unravel the relationship between consumption and class. Indeed, 'romance industries' strategically target young people of a marriageable age and actively engage in the creation of what Illouz (1997) calls the 'ritual of romantic consumption'. The following discussion compares young educated professionals and rural migrant workers in contemporary China to consider how class positions shape consumer desires, with a specific focus on two forms of 'romantic consumption'-wedding photos and diamond rings. These two forms of consumption are juxtaposed in this discussion not only because they are two key items of expenditure associated with romance and weddings but also more importantly, because they are both 'positional luxury goods' that have gone through various degrees of democratisation at different times. Given the connection and differentiation between these two forms of consumption, they are bound to play different roles in shaping classbased consumer desires. 
Among myriad romance and wedding-related consumption activities, bridal portraiture as a distinct cultural/social practice and consumption activity has consistently engaged the interest of anthropologists. This is evidenced in a special issue dedicated to this practice in Visual Anthropology more than a decade ago. Adrian's study (2006; see also Adrian 2003) of wedding rituals in Taiwan in the 1980s and 1990s reveals bridal portraiture in Taiwan to be a 'transnational visual phenomenon'. She observes that professionally produced bridal photography service originates from Taiwan and is different from wedding photographs taken by relatives and friends. ${ }^{2}$ In Adrian's view, bridal photography represents the democratisation of professionally produced high beauty, on the one hand, and of photography as a visual genre, on the other. From her fieldwork, we learn that the production of seemingly similar wedding photographs may be enacted and invested towards different ends, therefore pointing to the importance of exploring the relationship between visual images and the substance of the social lives through which these images emerge.

Bridal portraiture came to China from Taiwan in the late 1990s and since then has become one of the fastest growing industries in Hong Kong and China. In Hong Kong, the traditional ritual of marriage has changed considerably due to the widespread use of studio bridal photography and video recording. For middle-class women in China in the late 1990s and early 2000s, bridal photography afforded individuals an opportunity to engage in 'the cosmopolitan framings of the self' (Constable 2006: 43), and as such, can be read as visual evidence of people's efforts to live out the tension between the traditional and the modern, the Chinese and the Western. Constable's discussion about this cultural phenomenon in Beijing more than a decade ago ends with several questions for further research, one of which was, 'Who, among China's new under-classes, cannot afford such indulgences?' (Constable 2006: 53). Eric Ma's discussion of 'wedding imaginations' in South China, in the same issue of Visual Anthropology, does include some insights on rural migrants. Through an account of four wedding couples from different classes (lower versus middle) and social backgrounds (urban Chinese, rural Chinese, Hong Kong residents), Ma examines how visual competency, urban experience and economic capital-what Ma calls the 'three overlapping vectors'-intersect to shape the ways in which visuality exhibits and stabilises class status. In comparison with other couples in Ma's study, the rural migrant couple displayed a 'low level of visual competence and limited urban experience' did not subscribe to the 'subtle layers of visuality in wedding romances and myths' but thought that wedding photography was a 'trendy and modern thing to do' (Ma 2006: 61). By contrast, Kendall's study of the wedding hall photography among rural migrant working-class Koreans in the 1980s finds that wedding photography was more about producing 'necessary and important documents' and about 'authenticating claims to marital respectability' (Kendall 2006: 2). She argues that, however mass produced, wedding portraits are produced within and through the 'authenticating context of sacred and secular rituals of getting married' (4).

A decade and half after bridal photography reached Chinese cities and townships, bridal photography, which was then described by Constable as an 'indulgence', has now become more affordable to rural migrants and lower classes. In recent years, the number of professional wedding photography studios has increased by $10 \%$ each year, and the number of wedding dresses sold to these studios has increased by $20 \%$ annually (Ding, W. 2014). A 2011 study (Ling, Q. 2011) claims that there were then 450,000 
professional wedding photo studios employing around five million people in China. The same study suggests that around 10 million couples get married in China each year, most of them living in small cities and townships. For these couples, the cost of wedding photo shoots consumes up to $15 \%$ of the entire cost of their wedding.

The industry has also become increasingly stratified in terms of price, variety, professional standards and taste. At the low end, there are packages priced at a couple of thousand yuan that cater to the mass market and are available through online booking and group purchases. At the high end, one can easily expect to pay more than ten thousand yuan and to receive a highly personalised service in return, delivering to customers styles of romance that are increasingly individuated and technologically sophisticated. Catering mostly to millennials who are known for their more individualistic style of self-expression, the competitive wedding industry is forever on the lookout for more innovative and individuated themes, formats and aesthetics (Qianzhan Report 2014).

In comparison to professional wedding shoots, diamond engagement/wedding rings did not arrive in China until the 2000s, when De Beers started advertising them on Chinese television. Within a decade, the sales figures for diamond wedding rings had grown from zero to $10 \%$ of all spending on jewellery within China (Ritchie 2015). China is now one of the world's largest market for diamonds, with one report indicating that more than $30 \%$ of new brides now receive a diamond engagement ring. By mid 2010, $80 \%$ of newlyweds in Beijing had purchased a diamond ring (Meredith 2007), while around 75\% of couples in Tier 1 and Tier 2 cities had purchased one (Yuan 2016). Ranging from a few thousand to a few hundred thousand yuan, the price of a diamond ring could be equivalent to 5 months of salary for a young urban white collar employee-two to five times more than the 1- to 3-month 'salary rule' for how much a man should spend on a diamond purchase in the West (Russell 2010: 52-53). In fact, for the new rich and aspiring middle classes in China, fine jewellery has become the third most important consumer item after a house/flat and a personal car (Cartier 2008).

In recent years, there has been a tendency to produce diamond rings that are affordable to consumers who are outside the new rich and middle classes, with the low-cost jewellery market in Hong Kong trying to overcome the perception of the diamond as 'luxurious and unreachable' and promote diamond rings with smaller stones that are designed for everyday wear. For instance, De Beers is actively campaigning to target women between the ages of 18 and 29 and buyers in medium and small cities (Ritchie 2015). At the same time, while the diamond industry tries to facilitate the democratisation of the diamond ring, there is also the tendency among consumers towards 'maximalism'-a preference for large, flawless and expensive stones-a trend that is explained, on the one hand, by the consumer's desire to symbolise success and, on the other hand, by the cultural tradition of viewing expensive jewellery as a form of wedding equity, such as a dowry gift (Cartier 2008). All in all, it is safe to say that the capacity to afford a decent-sized De Beers engagement or wedding ring is still limited to white collar workers, even though this form of consumption has become widely popularised due to the 'demonstration effect' (Duesenberry 1949) of advertising and other marketing initiatives. Despite some degree of democratisation, the diamond ring still retains the status of a 'luxury good', embodying the paradox between social exclusion and aspirational consumption.

In what below, I ask how individuals from two socioeconomic cohorts think, talk and make decisions about these consumer goods and services. Adopting a qualitative research 
method, the paper presents empirical data which comes from ethnographic interactions and in-depth conversations with young men and women in their 20s and 30s from these two different social groups-both married and single. From August to October 2015, I spent time with rural migrant factory workers in the industrial complex of Longhua New District in Shenzhen, with a view to exploring how social inequality shapes these workers' views on and experiences of romantic love and romantic consumption. ${ }^{3}$ During that period, I interviewed 25 rural migrant workers, all of them workers at Foxconn, China's biggest global factory and manufacturer of parts for Apple and other electronics companies. ${ }^{4}$ These one-to-one interviews mostly lasted an hour and a half, often in the small, crowded rental rooms where workers lived, or occasionally in a café located in the residential areas of the industrial complex often described as a 'village within the city'. With an iPad in hand, I showed my interviewees images of commercially produced bridal photography and video clips of De Beers' engagement ring advertisements, which had originally screened on television. I invited them to comment on these images and used these visual prompts to begin what often turned out to be intimate conversations about their private emotional lives. In the hope of generating some comparable data which may shed light on possible differences and similarities between the two groups, I subsequently interviewed 12 young, educated white-collar professionals in Nanjing, Shanghai, and Beijing, using similar interview formats and conversational prompts. ${ }^{5}$

\section{Bridal photography as a social ritual}

Almost everyone I interviewed-men and women, urban professionals and rural migrants-thought that bridal photography was an essential part of the wedding ceremony these days. One particularly prominent reason, which was cited by individuals from both groups, was that having a formal wedding shoot is a key component of the ritual of getting married. Interviewees mentioned that the wedding is an occasion that families, relatives, friends and colleagues all participate in, so even though they themselves see little practical use for a wedding shoot, sharing these pictures with or displaying them to members of one's circle means that they perform an important social function. Another reason cited by young people from both groups was the sentimental value of a bridal portrait. Some said that they would like to have some visual evidence to remind themselves decades later of how young and attractive they once looked. Others mentioned that they wanted to give their children an opportunity to find out what their parents looked like when they were young. A saying that came up again and again in their justification was 'It [a wedding] is a ritual that happens only once in a lifetime, so of course we want to do it [have a photo shoot]'. Some mentioned that parents and relatives love to keep these images on their mobile phones and show them around, and colleagues and friends also expect them to post them on social media.

Shen S. and Zhao WB live in an apartment in downtown Nanjing. While Shen's parents helped with the payment of the deposit for the apartment, Shen and her husband are paying off the mortgage themselves. Shen works in a bank in the CBD, and her husband Zhao, whom she married a year ago, is a software programmer in a Japaneseowned company. When they met me for an interview-separately-both had pictures of their wedding on their mobile phones, and they were only too happy to share these with me. The package they had chosen was a 'combo' deal, showing them in various settings including exotic and 'sophisticated' backdrops featuring European-style and Art 
Deco furniture such as a chandelier, an antique desk and bookshelves full of old books, as well as a more 'natural' setting involving images of quiet cobblestone streets in an old town, serene gardens and tranquil rivers. Shen reminded me that hers was a 'common or garden' package that was 'nothing fancy': 'It cost us only a few thousand yuan; we didn't want to spend a lot of money on it so we chose a deal in the low price range'.

The couple look extremely elegant in these pictures, and Shen, wearing a white wedding gown that suggests understated sexiness, looks impossibly glamorous. Although I could see the resemblance between the people in the photos and the couple sitting in front of me-the issue of resemblance is also discussed in Constable's analysis-it is obvious that images of both of them, and especially, the bride, have been touched up: Shen has bigger eyes, fairer and smoother skin, slimmer arms, and a more slender body in these pictures. Sensing my amazement at the transformation, Shen laughed and said, 'The magic of software!'

All the young married couples working in professional jobs in Beijing and Nanjing who agreed to talk to me had had their photos taken in Western-style bridal gowns, but a few donned a traditional red Chinese jacket after that for some photos, just to add some variety. While a few treated the photo shoot as an opportunity for selfexpression, many others were content with whatever the commercial deal offered them. Liu YY, in his early 30s, has a rural background, but his tertiary and postgraduate education paid off and landed him a good job in Beijing. He is now a public servant in the Ministry of Hydraulics, is married with a young daughter, and is paying off the mortgage on an apartment he and his wife are buying. His photo shoot cost around 7000 yuan, which, by his reckoning, was well below the median price range for Beijing wedding shoots. Most of Liu's friends also opted for a package below the median price as they did not see much point in spending a lot of money on something that usually ends up 'at the bottom of the drawer'. He and his wife booked their photo shoot as part of a group, which entitled them to a discounted price.

These professional couples are aware that they are merely participating in a commonplace consumption activity and that there is nothing authentic and original about its form or content. Thus, Wen B., an IT consultant in Nanjing, mentioned that when he and his colleague shared their respective wedding photos on WeChat-the most popular social media platform in China-they were not surprised that they had used the same studio, opted for the same package, and ended up with almost identical settings and backdrops. The lack of originality did not bother him or his wife Sun S., who works in a bank and believes that convenience is a justifiable trade-off for the loss of individuality:

I have a colleague who is a music lover. She and her fiancé wanted to express their identity through music and wanted their wedding photos in the style of music video, so instead of booking a commercial package, they asked a friend to photograph them. They booked their own gown, chose their own locations, and organised the whole thing themselves. I've seen their photos-she showed me on her phone-and they're really good, and it cost them only about 1000 yuan, but it takes so much time and energy. Besides, these commercial studios have professional photographers, state-of-the-art equipment, and techniques for make-up, so, it's a one-stop shop. Very convenient. We're all already quite busy with life; who wants the extra hassle? 
Zhang, XW, a pre-primary school teacher in Nanjing in her mid-20s, was yet to find a boyfriend, but she already saw the logic of going for a commercial package:

Spending money will save you hassles. Doing it yourself means you need to spend lots of time putting on make-up. But you need someone to do that for you-someone who knows what they're doing. You'll have to rent costumes, arrange transport and get someone to carry your gear. Even if your friends are willing to help, you can't prevail on them to do everything. You end up owing favours. You feel you need to treat them to dinner for their trouble. Too much hassle. Not worth it. You're much better off paying for it.

Although most young people in this cohort are happy to go along with the ritual, some seem to have a jaded view about its purported association with love and romance. Huang F., a reporter with a big newspaper in Shanghai, was about to marry her boyfriend of many years when she talked to me. She has thought a lot about the ritual of the wedding banquet and wedding photos:

I personally think there is nothing romantic about wedding banquets and wedding photos. But I'll go along with all that because in China getting married is not just an individual matter between two people; it's about families. So, for the sake of parents and families, I'm prepared to be an actor once and appear in these photos as a puppet!

However, while owning a house/apartment and a car may be the most importan$\mathrm{t}$-and most expensive-evidence of their achievements in life, the wedding shoot, having become widely affordable, is an eminently suitable consumption choice to mark a step along the way towards these bigger material goals. Nevertheless, the choice of a 'suitable package' is likely to be made more on the principle of convenience and getting the 'best value' than as a conspicuous display of their emerging consumption power.

\section{You have to do it-it happens only once in a lifetime}

Like their urban professional counterparts, young rural migrants also believe that commemorating their wedding in photographic terms is a meaningful thing to do, since marriage is supposed to happen 'only once in a lifetime' and it is therefore important to mark it. In this sense, they are not dissimilar to their counterparts in Hong Kong, Taiwan and Korea, who use bridal portraiture to document, witness and authenticate an important ritual. At the same time, unlike their urban Chinese counterparts, the professional bridal photography among young rural migrants is more often than not an aspirational consumption, signifying a capacity to participate in the process of becoming urban and modern. Zhang Y.X., also at Foxconn, is yet to find a boyfriend, but she expects professional wedding photos to be an integral part of getting marrie$\mathrm{d}$-although she herself does not see the point of it except as a once-in-a-life-time excuse to indulge herself. Unlike urban professional Huang F. discussed earlier, who considers herself a reluctant 'actor' and a 'puppet' in these photo shoots, Zhang thinks this will be the only day in her life when she gets to be treated as special: 'I know why we [rural migrant workers] want to do it. It's because we're poor, and there are not that many legitimate excuses to indulge ourselves except for this'. Zhang's desire to be 
treated as someone special just for once in her lifetime echoes the sentiment expressed by rural migrant brides in Taiwan in Adrian's study (2006).

Second-generation rural migrants are more exposed to the urban lifestyle and consumerist values than their parents were and-unsurprisingly-are more keen to participate in urban consumption practices (Chu 2013). Keen to tap into the market of young rural migrant couples, yet cognisant of their limited consumption capacity, some commercial bridal photography studios occasionally offer complimentary photo shoots to a limited number of rural migrants (e.g. Xu and Zheng 2012). These events are staged with the main purpose of creating new clientele, positioning rural migrants as the new desiring consumers. Would rural migrants be interested in taking advantage of these complimentary events? I had imagined that some would say yes, as this would save them a huge sum of money, while others would say no, since not everyone wants to be the recipient of middle-class charity. While both speculations turned out to be true, the reasons workers gave for their decisions are complex. Li WJ, a Foxconn worker in her late 20s, is still looking for a boyfriend, but she is adamant that she will not be interested in a free wedding photo shoot:

It's not that I don't like a gift, but a wedding is something that happens only once in a lifetime, and you have to think of what your parents, family, relatives and friends would say. They may not accept it. What's more, nowadays the cost of a professional wedding photo shoot is not that high. A couple of thousand yuan. You could have a fairly good one with two months' salary. So I may sign up for a free event such as this just for fun, but will still have a proper one as part of my wedding.

In other words, $\mathrm{Li}$ and her family/friends would be happy to accept a commercial package at the low end of the market, as long as it is not free. To them, romantic practices such as this would not be legitimate unless they are purchased. And it is not just women who are subject to this social pressure. Cao ZL, a young man also working at Foxconn, echoed Li WJ's reservation but was more explicit about why: 'I'd lose face. My family would lose face. It would make my wedding look shabby. 'People would think we are cheapskates, wanting to save a bit of money on the most important event in our lives'.

Qing ZB, another unattached Foxconn assembly line worker in his late 20s, said that he would love to take advantage of a free photo shoot but he is confident that most women would not go along with that. And having dated quite a few women, he seemed fairly certain about what this imaginary 'she' would say:

She will say, 'There's no such thing as a free lunch in this world; how can you prove to me that you love me without wanting to spend any money [on such an important event]?' She'll also say, 'Am I worth nothing to you?'

Qin ZB echoes the sentiment of many rural migrant men who have their dream of romantic love dashed by the inferior financial circumstances they find themselves in. As Choi and Peng (2016) point out in their study of rural migrant men, rural-to-urban migrant men face inequalities on both fronts-they need to compete with more wealthy urbanites and better off rural counterparts.

It is obvious that both young urban professionals and young rural migrant embrace this ritual of romantic consumption and both cite familial and social expectations as an 
important consideration. Individuals from both groups make it clear that they would be happy with a low-end package deal. But their reasons behind such a decision could not be more different. For young urban professionals, this consumption practice has more or less been de-coupled from connotations of power and social status. These packages are widely taken up by young and busy couples as a practical alternative to options that, while more individualistic, would be much more time- and energy-consuming. In the same way that they can outsource domestic work, they are also outsourcing emotional work. But the democratisation of this once-upon-a-time luxury good is a double-edged sword. For cash-strapped rural migrants, on the other hand, the stakes are a lot higher if they forego the ritual in order to save few thousand yuan. For them, this ritual of romantic consumption is not a matter of choice; it is almost obligatory. They are not so much paying for this service to have emotional work outsourced; they are paying for it in order to 'keep up with the Joneses'. For members of this community, like the working-class Koreans in Kendell's study, the act of consumption has become a highly recognisable means of giving 'face' and gaining respectability and legitimacy within their own community. The ritual of getting married is not legitimate unless and until mediated by the market.

Statements from individuals I interviewed attest to Adrian's argument that although people of different classes engage in the same ritual of romantic consumption, how and why they do so is significantly shaped by their socioeconomic status and occupational identity. Urban professional couples may choose to take a pragmatic, or ironic, or individualistic and non-commercial approach to the question of how to document a once-in-a-lifetime moment. For them, it is a matter of choice. In comparison with their urban professional counterparts, young rural migrants seem more susceptible to interpellation into the market ideology of romance. They are less critical of its formulaic nature and are more likely to treat it as what Sara Ahmed (2010: 26) calls 'happy objects'-things 'which become good or acquire their value as goods insofar as they point towards happiness'. Since the question of legitimacy-in social and cultural terms-is key to aspirational consumption, and since this legitimacy is certifiable only through the act of consumption, many rural migrants' insistence on paying for a professional wedding photography service-even if a free one is available-is poignant but understandable. After all, thanks to the democratisation of this service, the wedding shoot has become one thing these workers can afford to participate in the modern and urban life and to exercise their agency as consumer citizens.

\section{The diamond ring-a girl's best friend?}

While the price of wedding photos has come down enough to admit consumers from lower socioeconomic groups, the diamond engagement ring is still very much a positional goods that is beyond rural migrant consumers. This does not mean, however, that rural migrants are not interested in, or immune from, the ideology of romance that the diamond industry promotes. One De Beers advertisement features an attractive, glamorous-looking couple stepping out of a party and coming to stand at the edge of a pool to enjoy a moment of intimacy. The woman looks up at the sky and says, 'What a beautiful moon!' On hearing this, the young man says, 'Like it? I'll get it for you'. With this, he dives into the moonlit pool and, a second later, resurfaces holding a diamond ring. Surprised, the woman smiles with happiness. The voiceover says, 'A diamond is forever, just like your love'. In another ad, a young man leads his girlfriend to a garden 
maze, blindfolds her, and ties a red thread between her finger and his at the other end of the maze. He then slides a diamond ring along the thread, which travels across the maze and lands on her ring finger. The girl opens her eyes, sees the ring on her finger, looks surprised, and then seems overcome with happiness. Then the same voiceover: 'A diamond is forever, just like your love'.

Many rural migrant women, especially the younger ones (born in the 1990s) were wowed by these ads. 'So romantic!' was their first gushy response. One said:

I don't expect to be given a diamond ring. It's too expensive for people like us. But I like the romantic feeling communicated by the ads. The idea of getting the moon is clever; who wouldn't be moved by a man who would do anything to make you happy? I love romance like this. Yes, I find it very moving.

The magic of romance also worked for another rural migrant woman: 'If one day my boyfriend gave me a surprise in this way, I'd be very happy, too, even though the ring may not have a diamond on it, and may cost much less'.

The De Beers ads were very effective in inculcating the idea of romance in these women viewers-even though they do not (yet) have the buying power to afford one. This aim was borne out by comments from a Shanghai-based industry informant who had been involved in the strategic planning for these ads at J. W. Thompson, the advertising company that made them. He confirmed that their main intention had been to widen the market base for strategic future development. When asked about the thinking behind the advertisement featuring the party and pool, my informant confirmed that a key strategy was to 'ensure that the audience understood that the couple were already in a relationship and they had stepped out of the party to catch some romantic time alone. It was important that they were not dressed too glamorously so as to suggest too high a status. They had to be aspirational, yet their aspiration had to seem achievable, and that would make the diamond itself seem more achievable without compromising on its desirable status' (personal communication, 2016).

While the De Beers ads succeeded in appealing to young migrant women, it did not anticipate a backlash from migrant men. Responses from migrant men could not be more different from their female counterparts, ranging from resignation to indignation. Qing ZB, quoted earlier, says:

Romantic? Give me a break! If I could, I'd block the TV so my girlfriend can't see it. It's bad enough already for us men, because we're expected to buy a flat and pay for the cost of the wedding. Now they've come up with yet another thing my girlfriend will pressure me to buy.

For such young rural migrant worker males, advertisers' attempts to link diamonds with the meaning of romance and love is injurious both to their identity as men and to their relationships with their girlfriends. Since women embrace the ideology of romance that is embodied in these ads, and are positioned by them as aspiring buyers of the future, migrant men see the diamond ring as potentially another point of disagreement between them. Qing's co-worker is less anguished. 'No, they [women] know we can't 
afford that, and if they're sensible, they'll be just as happy with a ring that costs a couple of hundred yuan and has a bit of gold in it'.

In comparison to rural migrant women, educated young professional women are much less susceptible to this marketised idea of romance, even though they seem more desirous of obtaining it. Shen, the bank clerk in Nanjing quoted earlier, may have been blasé about bridal photography (she booked hers online), but she was serious about the purchase of a diamond ring and told her fiancé that this would be absolutely essential. Rather than waiting for her fiancé to surprise her 1 day, as depicted in the ads, she enlisted him into investing quite a few weekends with her, trekking between many jewellery shops in Nanjing, before finally settling on her ring of choice: a half-carat diamond engagement ring costing 20,000 yuan. But prior to these shopping expeditions, Shen had spent hours browsing online, 'doing homework', in her own word, looking at countless images of diamond rings, searching for one which meets her criteria in terms of style and price range.

She seldom wears it, as it is not convenient while you are doing housework. To Shen, the symbolic value of a diamond ring is not its association with romance, but its capacity to indicate status. She mentioned that all the young women in her workplace have diamond rings, and from time to time, 'girl talk' in the office would involve sharing images on diamond rings on their mobile phone and gravitate towards the topic of who has the biggest and the most expensive one. 'Us girls, we are vain, you know', she laughed. According to Shen, one colleague's diamond ring is one carat, and is worth about 100,000 yuan-she added that she had seen the image of the ring on the phone. At half a carat, her own diamond ring falls somewhere in the middle of the price range. When I asked her if it is always the case that 'the bigger, the better' when it comes to diamonds, she said, 'Absolutely!'

If a diamond is a white collar professional girl's best friend, their fiancés and husbands know that a diamond ring speaks most eloquently about his capacity to meet her desires. The demonstration of this capacity seems particularly important to young 'white collar' men from rural areas and small towns or from more humble family backgrounds who have moved up the social ladder. Now living cheek by jowl with those urban folk who feel more secure about their middle-class status, the social mobility they have achieved may not always come with a sense of security. Li WR, a Hubei native with a postgraduate degree, now lives in Beijing with her husband and child. Her husband comes from a rural provincial family, but through education-he also has a postgraduate degree-he has become one of the few who have 'made it'. Both $\mathrm{Li}$ and her husband work in a municipal procurator's office in Beijing, she as a judge and he as a prosecutor. The couple are paying off the mortgage on their apartment. Li told me that she would have been happy enough to have a gold engagement ring but her husband 'wouldn't have it'. He said, 'Who do you take me for? I'm not so poor that I can't afford to buy a diamond engagement ring. I don't know anyone who doesn't have one. Of course you should have one, just like everyone else'. Li was clearly very proud of her husband when she recounted this exchange to me.

The diamond was an object of desire for white collar women like Shen and Li at least in part because it could work as a consolation or even compensation if love ends up being not quite everlasting. Li was moved by her husband's declaration of love through the purchase of a diamond ring, but her reason for accepting this offer seems to be the antithesis of romance: 
This is what I thought at that moment: Men may get rich 1 day and they may take on a lover. If that happens with my husband, what will that leave me? So I thought a woman should not be too hard on herself. She should get what she can while she's still young. That way, she may not feel so short-changed when she gets old and 1 day finds that her husband has taken up with another woman.

By now, it should be clear that myriad kinds of affect are being inscribed onto a piece of stone. As these statements indicate, these inscriptions are class- and gender-specific. For a woman, a diamond ring may express her desire for love and romance, but it may also encapsulate her anxiety and insecurity about the fragility and precarity of these feelings. For a man, a diamond may be a signifier of his success in achieving upward social mobility, but it could also be a means of testing his masculinity and proving his love for the woman in his life. As a positional good, the diamond engagement ring functions as a marker of class, and at this stage it works to highlight, rather than erode, social and economic disparity.

\section{Conclusion}

China has undergone profound social transformation over the last few decades. As a result of this, individuals are now living not only under the 'shadow of ancestors' (Hsu 1948) - traditional ideas of the self, family and interpersonal relationships-but also under the influence of global capitalist cultural forms and practices. Increasingly, individuals in China need to negotiate this tension in their everyday decisions, including, for example, whether and to what extent to participate in the capitalist ideology of 'romantic utopia'. Bridal photography featuring Western-style bridal dresses and advertisements of De Beers' engagement diamond rings both capture this cultural contradiction.

This discussion about the consumption practices of two social groups in contemporary China offers some clues to the transitional nature of social change in contemporary China, where class identities are relatively new and more volatile, and class structures are less clearly defined. This transitional nature in the change of social structures has at least two implications. While it is true that the middle class in China has the means to define and shape the dominant meanings of love and romance, individuals from the aspiring middle classes, especially the 'young white collar' cohort, are not necessarily in a position to achieve 'autonomy' through alternative and more individualistic romantic practices. Young urban professionals' collective fetishisation of the diamond ring suggests that their anxiety to maintain probationary membership of the middle class and their fear of falling out of it means that they are less interested in achieving autonomy and exploring alternative, individualistic romantic practices, and more interested in consolidating their belonging to that class by adopting similar consumption practices to those who had already made to the middle-class status.

Furthermore, the transitional nature of social restructuring also means that the formation of class relations through the consumption of luxury goods can sometimes take place in more uncertain and predictable ways. Individuals' thinking and decisionmaking processes, increasingly occurring in highly mediated visual genres, formats and platforms, are indeed points of contact between objects and symbols, between commodities and desire, and between action and perception. These points of contact mediate individuals' aspirational desire for upward social mobility as well as their anxiety 
about the possibility of downward social mobility, and in doing so, they simultaneously highlight and obscure the boundary between classes. Nobody seems interested in speaking the 'language of consumerist solidarity' across class.

This discussion also highlights the importance of viewing the democratisation of luxury goods as an ongoing, open-ended process, as well as its implication on our thinking on class and consumption. First, the notion of 'luxury' is class-specific: one class's luxury is another class's everyday consumption. Second, what counts as luxury is subject to constant change: today's luxury goods may be 'common or garden' variety goods tomorrow. Third, individuals' class identity formation through consumption is invariably shot through the lens of gender. Finally, consumers need to be positioned in ways that appeal simultaneously to their aspiration to belong and to their anxiety about not belonging.

\section{Endnotes}

${ }^{1}$ For a recent discussion of the diversity within this group, the politics of the naming of nongmingong, and the similarities and differences between this group and laidoff state factory workers and the urban poor, see Sun (2014).

${ }^{2}$ For a detailed account of how bridal photography differs from conventional wedding photos, see papers by Adrian and Constable in the special issue of Visual Anthropology.

${ }^{3}$ While the term 'rural migrant worker' encompasses various types of employment, $35.7 \%$ of the labour force is in manufacturing sector, being the largest employment group (Author). The migrant workers discussed in this paper come from this particular cohort.

${ }^{4}$ Foxconn is a Taiwanese-owned electronics manufacturer that has plants in various parts of China, with its plant in Shenzhen being the earliest and biggest. As China's biggest global factory and manufacturer of parts for Apple and other electronics companies, Foxconn employs young and mostly unmarried workers, most of them with rural hukou status. For discussions of labour conditions and Foxconn workers' experience with the industrial regime, see Chan and Pun (2010) and Selden, Pun, and Chan (2013).

${ }^{5} \mathrm{My}$ interaction with Shenzhen's rural migrant factory workers is longitudinal and ethnographic in nature. Since my initial meetings in 2015, I have stayed in touch with them via social media. In October 2016, I conducted follow-up face-to-face interviews with 10 of these individuals during my four-week stay in the same location. In contrast, my interviews with the urban professional group, arranged by my China-based research assistant, mostly took the form of one-off meetings in late 2015.

Competing interests

The author declares that she has no competing interests.

Received: 2 May 2017 Accepted: 22 September 2017

Published online: 30 September 2017

References

Adrian, Bonnie. 2003. Framing the Bride: Globalizing Beauty and Romance in Taiwan's Bridal Industry. Berkeley: University of California Press.

Adrian, Bonnie. 2006. Geography of style: Taiwan's bridal photography empire'. Visual Anthropology 19: 73-85.

Ahmed, Sara. 2010. The Promise of Happiness. Durham: Duke University Press.

All China Workers' Union (2010) All China Workers' Union Research Team Reports that 80\% of the 100 million secondgeneration migrant workers are not married [全国总工会新生代农民工问题课题组, 报告称中国现有约1亿新生 代农民工 近八成未婚]. China News Service [中国新闻网], 21 June. Available at: http://news.xinhuanet.com/201006/21/C_12242539.htm (Accessed 17 August 2016). 
Bourdieu, Pierre. 1984. Distinction: A Social Critique of the Judgment of Taste. Translated by Richard Nice. Cambridge: Harvard University Press.

Cartier, Carolyn. 2008. The Shanghai-Hong Kong connection: Fine jewelry consumption and the demand for diamonds. In The New Rich in China: Future Rulers, Present Lives, ed. David S.G. Goodman, 187-200. London: Routledge.

Chan, Jenny and Ngai Pun (2010) "Suicide as protest for the new generation of Chinese migrant workers: Foxconn, global capital, and the state." The Asia-Pacific Journal 37, 2, 13 September. http://japanfocus.org/Jenny-Chan/3408 (Accessed 3 April 2017).

Chan, Kam Wing, and Will Buckingham. 2008. Is China abolishing the hukou system? China Quarterly 195: 582-606. Chen, Minglu, and David S.G. Goodman, eds. 2013. Middle Class China: Identity and Behavior. Cheltenham: Edward Edgar.

Choi, Susanne Yuk-Ping, and Yinni Peng. 2016. Masculine Compromise: Migration, Family, and Gender in China. Berkeley: University of California Press.

Chu, Y. (2013) Rural migrant youths born in the 1990s like to shop online according to a consumption survey ['90后'新 生代农民工消费状况调查 都爱网购]. Morning News [今日早报], 24 May. Available at: http://finance.ce.cn/ rolling/201305/24/t20130524_17116912.shtml (Accessed 17 August 2016).

Constable, Nicole. 2006. Nostalgia, memory, and modernity: Bridal portraits in contemporary Beijing. Visual Anthropology 19: 39-55.

Ding, Wanqing (2014) Weddings become a vanity fare; is there still love? [婚礼成了名利场 爱情还能走多远] , 13 May. Available at: http://www.qianzhan.com/analyst/detail/220/140513-8fd0f5b7.html (Accessed 17 August 2016).

Duesenberry, James S. 1949. Income, Saving, and the Theory of Consumer Behavior. Cambridge: Harvard University Press.

Guo, Yingjie. 2008. Class, stratum and group: The politics of description and prescription. In The New Rich in China: Future Rulers, Present Lives, ed. David S.G. Goodman, 38-52. London: Routledge.

Hanser, Amy. 2008. Service Encounters: Class, Gender, and the Market for Social Distinction in Urban China. Stanford: Stanford University Press.

Hanser, Amy. 2010. Uncertainty and the problem of value: Consumers, culture and inequality in urban China. Journal of Consumer Culture 10 (3): 307-332.

Hirsch, Fred. 1976. Social Limits to Growth. Cambridge: Harvard University Press.

Hsu, Francis L.K. 1948. Under the Ancestors' Shadow: Chinese Culture and Personality. New York: Columbia University Press.

Illouz, Eva. 1997. Consuming the Romantic Utopia: Love and the Cultural Contradictions of Capitalism. Berkeley: University of California Press.

Kendall, Laurel. 2006. Something old ... Remembering Korean wedding hall photographs from the 1980s. Visual Anthropology 19: 1-19.

Li, Chunling. 2013. Sociopolitical attitudes of the middle class and the implications for political transition. In Middle Class China: Identity and Behaviour, ed. Minglu Chen and David S.G. Goodman, 12-33. Cheltenham: Edward Elgar Publishing.

Ling Q. (2011) An analysis of the growth of the wedding gown industry [婚纱摄影行业发展分析], 21 October. Available at: http://wenku.baidu.com/view/5de91422dd36a32d7375815f.html (Accessed 17 August 2016).

Ma, Eric. 2006. Realizing wedding imaginations in South China. Visual Anthropology 19: 57-71.

Meredith, Robyn. 2007. The Elephant and the Dragon: The Economic Rise of India and China, and What it Means for All of Us. New York: WW Norton.

National Bureau of Statistics (2016) A 2015 survey report on rural migrants [2015年农民工监测调查报告], 28 April. Available at: http://www.stats.gov.cn/tjsj/zxfb/201604/t20160428_1349713.html (Accessed 17 August 2016).

Otis, Eileen M. 2012. Market and Bodies: Women, Service Work, and the Making of Inequality in China. Stanford: Stanford University Press.

Pun, Ngai. 2005. Made in China: Women factory workers in a global workplace. Durham: Duke University Press.

Qianzhan Report (2014) A report on the market and investment pattern for China's wedding industry from 2014 to 2018 [2014-2018年中国婚庆产业市场研究与投资预测分析报告]. Available at: http://bg.qianzhan.com/report/ detail/cf9e74b3c7d14abc.html (Accessed 17 August 2016).

Ritchie, Martin (2015) De beers pushes gift-giving to halt China's diamond slowdown, 22 September. Available at: http://www.bloomberg.com/news/articles/2015-09-22/de-beers-pushes-gift-giving-to-arrest-china-s-diamondsslowdown (Accessed 17 August 2016).

Rocco, Jean-Louis. 2017. The Making of the Chinese Middle Class: Small Comfort and Great Expectations. New York: Palgrave Macmillan.

Russell, Rebecca R. 2010. Gender and Jewellery: A Feminist Analysis. CreateSpace Independent Publishing.

Saunders, Doug (2015) Struggling to succeed: Behind China's crisis, consumers driven underground-literally. The Globe and Mail, 21 August. Available at: http:/www.theglobeandmail.com/news/world/the-ant-tribe-of-china/ article26054666/ (Accessed 17 August 2016).

Selden, Mark, Ngai Pun and Jenny Chan (2013) "The politics of global production: Apple, Foxconn and china's new working class." The Asia-Pacific Journal 11, 32/2, 8 August. http://www.japanfocus.org/-Jenny-Chan/3981 (Accessed 3 April 2017).

Sun, Wanning. 2009. Maid in China: Media, Morality, and the Cultural Politics of Boundaries. London: Routledge. Sun, Wanning. 2014. Subaltern China: Rural Migrants, Media and Cultural Practices. Lanham, MD: Rowman \& Littlefield. Tomba, Luigi. 2014. The Government Next Door: Neighbourhood Politics in Urban China. Ithaca: Cornell University Press. Veblen, Thorstein. 2006. [1899] The Theory of the Leisure Class. Oxford: Oxford University Press.

Weber, Max. 1922. Economy and Society: An Outline of Interpretive Sociology. Berkley: University of California Press.

$\mathrm{Xu}$, J., and Y. Zheng (2012) Korean photography studio helps realise rural migrants' dream of wearing a wedding gown [韩国摄影师圆基层打工者婚纱梦，中国新闻网]. Available at: http://daguu.com/pc/news/detail/114.htm (Accessed 13 November 2016). 
Yan, Hairong. 2008. New Masters, New Servants: Migration, Development, and Women Workers in China. Durham: Duke University Press.

Yuan, M. (2016) According to American press, every man and woman loves a diamond wedding ring [美媒:中国的结 婚必需品一钻戒, 男女都爱]. The Paper, 31 January. Available at: http://m.thepaper.cn/newsDetail_forward_ 1427798?from=singlemessage\&isappinstalled=0 (Accessed 17 August 2016).

Zhang, Li. 2010. In Search of Paradise: Middle-Class Living in a Chinese Metropolis. Ithaca: Cornell University Press.

Zukin, Sharon, and Jennifer Maguire. 2004. Consumers and Consumption. Annul Review of Sociology 30: 173-197.

\section{Submit your manuscript to a SpringerOpen ${ }^{\circ}$ journal and benefit from:}

- Convenient online submission

- Rigorous peer review

- Open access: articles freely available online

- High visibility within the field

- Retaining the copyright to your article

Submit your next manuscript at $>$ springeropen.com 